\title{
Desulfatirhabdium butyrativorans gen. nov., sp. nov., a butyrate-oxidizing, sulfate-reducing bacterium isolated from an anaerobic bioreactor
}

\author{
Correspondence \\ Melike Balk \\ Melike.Balk@wur.nl
}

\author{
Melike Balk, ${ }^{1}$ Mahmut Altınbaş, ${ }^{1,2}$ W. Irene C. Rijpstra, ${ }^{3}$ \\ Jaap S. Sinninghe Damsté ${ }^{3}$ and Alfons J. M. Stams ${ }^{1}$
${ }^{1}$ Laboratory of Microbiology, Wageningen University, Dreijenplein 10, 6703 HB Wageningen, The Netherlands Turkey
${ }^{3}$ Department of Marine Biogeochemistry and Toxicology, Royal Netherlands Institute for Sea Research, PO Box 59, 1790 AB Den Burg (Texel), The Netherlands \\ ${ }^{2}$ Department of Environmental Engineering, Istanbul Technical University, 34469 Maslak, Istanbul,
}

\begin{abstract}
A novel sulfate-reducing bacterium, strain $\mathrm{HB}^{\top}$, was isolated from an upflow anaerobic sludge blanket (UASB) reactor treating paper-mill wastewater operated at $37{ }^{\circ} \mathrm{C}$. Cells of strain $\mathrm{HB} 1^{\top}$ were oval to rod-shaped, 1-1.3 $\mu \mathrm{m}$ wide and 2.6-3.5 $\mu \mathrm{m}$ long and Gram-negative. The optimum temperature for growth was $28-30{ }^{\circ} \mathrm{C}$. In the presence of sulfate, the isolate was able to grow on $\mathrm{H}_{2}$ /acetate, formate, ethanol, propionate, fumarate, succinate, butyrate, crotonate, catechol, benzoate, 4-hydroxybenzoate, palmitate and stearate. The isolate only grew on $\mathrm{H}_{2}$ when acetate was added as a carbon source; when grown on formate, acetate was not required. Growth was also possible on pyruvate and crotonate without an electron acceptor. The isolate showed very poor growth on acetate. Thiosulfate and sulfate were used as electron acceptors. Phylogenetic analysis of $16 \mathrm{~S}$ rRNA gene sequences revealed that strain $\mathrm{HB}^{\top}{ }^{\top}$ represents a novel lineage within the Deltaproteobacteria; sequence similarities between strain $\mathrm{HB}^{\top}$ and members of other related genera were less than $91 \%$. Strain $\mathrm{HB}^{\top}$ was also distinguished from members of related genera based on differences in several phenotypic characteristics. It is a member of the family Desulfobacteraceae. The major cellular fatty acids of strain $\mathrm{HB}^{\top}$ were $\mathrm{C}_{16: 0}$, iso- $\mathrm{C}_{15: 0}$, anteiso- $\mathrm{C}_{15: 0}$ and $\mathrm{C}_{14: 0} \beta$-Hydroxy fatty acids were also present in the range

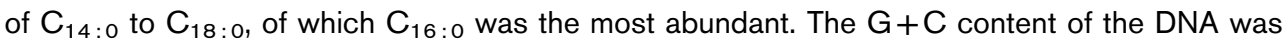
$55.1 \mathrm{~mol} \%$. Based on physiological, biochemical and chemotaxonomic traits together with results of comparative $16 \mathrm{~S}$ rRNA gene sequence analysis, strain $\mathrm{HB}^{\top}{ }^{\top}$ is considered to represent a novel species in a new genus, for which the name Desulfatirhabdium butyrativorans gen. nov., sp. nov. is proposed. The type strain of Desulfatirhabdium butyrativorans is $\mathrm{HB}^{\top}{ }^{\top}$ (=DSM $18734^{\top}=$ JCM $14470^{\top}$ ).
\end{abstract}

Dissimilatory sulfate reduction is the most important anaerobic process in many different environments (e.g. Jørgensen, 1982; Canfield et al., 1993; Thamdrup \& Canfield, 1996; Rysgaard et al., 1998; Kostka et al., 1999; Glud et al., 2000; Rabus et al., 2006). Bacterial sulfatereducers fall into different branches, the Deltaproteobacteria, with more than 25 genera, the Gram-positive bacteria, including genera such as Desulfotomaculum (Campbell \& Postgate, 1965) and Thermodesulfobium (Mori et al., 2003), and Gram-negative sulfate-reducers

Abbreviation: UASB, upflow anaerobic sludge blanket.

The GenBank/EMBL/DDBJ accession number for the $16 \mathrm{~S}$ rRNA gene sequence of strain $\mathrm{HB}^{\top}{ }^{\top}$ is $\mathrm{DQ} 146482$. such as the genera Thermodesulfobacterium (Zeikus et al., 1983) and Thermodesulfatator (Moussard et al., 2004) within the class Thermodesulfobacteria and Thermodesulfovibrio (Henry et al., 1994) within the class 'Nitrospira'.

Although the Deltaproteobacteria is not a large assemblage of genera, its members show considerable morphological and physiological diversity (Rabus et al., 2006). Members of the family Desulfobacteraceae in the order Desulfobacterales are widely distributed in freshwater, marine, hypersaline and oil- or hydrocarbon-polluted sediments (Bak \& Widdel, 1986; Brysch et al., 1987; Szewzyk \& Pfennig, 1987; Gogotova \& Vainstein, 1989; Schnell et al., 1989; Rees \& Patel, 2001; Cravo-Laureau et al., 2004; Kjeldsen et al., 2007). These bacteria are anaerobic, 
mesophilic, Gram-negative, oval to coccoid, slightly curved or rod-shaped and grow optimally at $20-35{ }^{\circ} \mathrm{C}$. A wide variety of substrates including alcohols, fatty acids and aromatic and aliphatic compounds can be utilized by this group of organisms (Kuever et al., 2005). Members of the family Desulfobacteraceae play an important role in the degradation of volatile fatty acids in anaerobic bioreactors treating sulfate-rich wastewaters, such as those from paper mills, tanneries or the food oil industry (Oude Elferink et al., 1994; Colleran et al., 1995; Roest et al., 2005). Acetate and butyrate are important intermediates in the anaerobic degradation of wastewaters. Some bacteria in the family Desulfobacteraceae are able to oxidize butyrate either incompletely to acetate or completely to carbon dioxide with concomitant reduction of sulfate to sulfide (Stieb \& Schink, 1989; Platen et al., 1990; Brandt et al., 1999).

The microbial community of an upflow anaerobic sludge blanket (UASB) reactor treating paper-mill wastewater (Industriewater, Eerbeek, The Netherlands) was investigated. In this reactor, both sulfate reduction and methanogenesis have been found to be important (Oude Elferink et al., 1998). In a previous study, the dominant micro-organisms present in the anaerobic paper-mill wastewater treatment system were assessed by molecular techniques (Roest et al. 2005). As it was not clear from these earlier molecular studies which bacteria were involved in butyrate degradation with sulfate, in the present study, particular attention was paid to bacteria that are able to degrade butyrate with sulfate. Here, we report the taxonomic characterization of strain $\mathrm{HB}^{\mathrm{T}}$, which was isolated from granular sludge of the full-scale mesophilic UASB reactor at Eerbeek. Detailed characteristics of the granular sludge were described previously by Oude Elferink et al. (1998). About $10 \mathrm{ml}$ granular sludge was disintegrated by a Potter homogenizer (Tamson). Serial dilutions of the homogenized sample were prepared in a bicarbonate-buffered anaerobic medium containing sodium butyrate and sodium sulfate. Bacterial growth was evident at a dilution of $10^{-8}$ of the incubation at $37^{\circ} \mathrm{C}$ within 30 days.

Dilution series were made in a basal bicarbonate-buffered medium containing $10 \mathrm{mM}$ sodium butyrate with $20 \mathrm{mM}$ sodium sulfate. The basal liquid culture medium contained ( $\mathrm{g} \mathrm{l}^{-1}$ unless indicated): $\mathrm{NaCl}(7), \mathrm{NaHCO}_{3}(4), \mathrm{Na}_{2} \mathrm{SO}_{4}$ (2.8), $\mathrm{MgCl}_{2} \cdot 6 \mathrm{H}_{2} \mathrm{O}$ (1.2), $\mathrm{KCl}(0.5), \mathrm{NH}_{4} \mathrm{Cl}(0.3), \mathrm{KH}_{2} \mathrm{PO}_{4}$ (0.2), $\mathrm{CaCl}_{2}(0.15), \mathrm{Na}_{2} \mathrm{~S} .7-9 \mathrm{H}_{2} \mathrm{O}(0.3)$, yeast extract (0.02), selenite/tungstate solution $\left(1 \mathrm{ml} \mathrm{l}^{-1}\right)$ (Widdel \& Bak, 1992) and a trace element solution $\left(1 \mathrm{ml} \mathrm{l}^{-1}\right)$ containing $\left(\mathrm{mg} \mathrm{l^{-1 }}\right.$ unless indicated): $\mathrm{FeCl}_{2} \cdot 4 \mathrm{H}_{2} \mathrm{O}$ (1500), $\mathrm{CoCl}_{2} \cdot 2 \mathrm{H}_{2} \mathrm{O}$ (190), $\mathrm{MnCl}_{2} \cdot 4 \mathrm{H}_{2} \mathrm{O}$ (100), $\mathrm{ZnCl}_{2}$ (70), $\mathrm{H}_{3} \mathrm{BO}_{3}$ (62), $\mathrm{Na}_{2} \mathrm{MoO}_{4} \cdot 2 \mathrm{H}_{2} \mathrm{O}$ (36), $\mathrm{NiCl}_{2} \cdot 6 \mathrm{H}_{2} \mathrm{O}$ (24), $\mathrm{CuCl}_{2} \cdot 2 \mathrm{H}_{2} \mathrm{O}(17)$, EDTA (500) and $37 \% \mathrm{HCl}(7 \mathrm{ml}$ $\left.1^{-1}\right)$. In addition, vitamins were added from a concentrated stock solution according to Stams et al. (1983). The cultures were grown routinely in $117 \mathrm{ml}$ serum vials with butyl rubber stoppers and aluminium crimp seals. The vials contained $50 \mathrm{ml}$ basal medium and a gas phase of 1.7 bar
$\mathrm{N}_{2} / \mathrm{CO}_{2}$ or $\mathrm{H}_{2} / \mathrm{CO}_{2}(80 / 20 \%$, v/v). Concentrated stock solutions of substrates were prepared anoxically, sterilized by filtration and added to the medium to final concentrations of 5-20 mM. Besides the substrates, vitamins, $\mathrm{CaCl}_{2}$, $\mathrm{NaHCO}_{3}$ and $\mathrm{Na}_{2} \mathrm{~S} .7-9 \mathrm{H}_{2} \mathrm{O}$ were added from stock solutions after sterilization of the medium. The $\mathrm{pH}$ of the medium was 7. Unless stated otherwise, all cultivations were carried out at $30{ }^{\circ} \mathrm{C}$.

For isolation, the enriched culture was incubated in the presence of butyrate by using the soft-agar dilution method. This procedure was applied in $117 \mathrm{ml}$ serum vials. Colonies, which were visible after 1 month of incubation, were picked with a sterile needle and subcultured in liquid medium containing butyrate and sulfate. The colonies were about $1 \mathrm{~mm}$ in diameter, lensshaped and brownish. Serial agar and liquid dilutions were repeated until a pure culture was obtained.

Microscope observations were performed with a Leica DC250 photomicroscope. Cells of strain $\mathrm{HB}^{\mathrm{T}}$ were oval to rod-shaped, 1-1.3 $\mu \mathrm{m}$ wide and 2.6-3.5 $\mu \mathrm{m}$ long, depending on the growth phase (Fig. 1). The cells stained Gramnegative (Murray et al., 1994). The cells were non-sporeforming and occurred singly, in pairs or in long chains.

The purity of the culture was checked by phase-contrast microscopy. Purity of the isolate was confirmed by incubations at different temperatures between 20 and $65{ }^{\circ} \mathrm{C}$ under anaerobic and aerobic conditions in media containing $10 \mathrm{~g}$ yeast extract $\mathrm{l}^{-1}$ or in anaerobic WilkinsChalgren broth (Oxoid).

Temperature limits for growth were determined by culture incubation from 10 to $65{ }^{\circ} \mathrm{C}$ in the basal medium. The $\mathrm{pH}$ limits for growth were determined in the same medium adjusted to $\mathrm{pH}$ values between 5 and 9 by changing the $\mathrm{CO}_{2}$ content of the gas phase. The dependence of growth on $\mathrm{NaCl}$ concentration was determined in basal medium containing $\mathrm{NaCl}$ at concentrations ranging from 0 to $40 \mathrm{~g}$

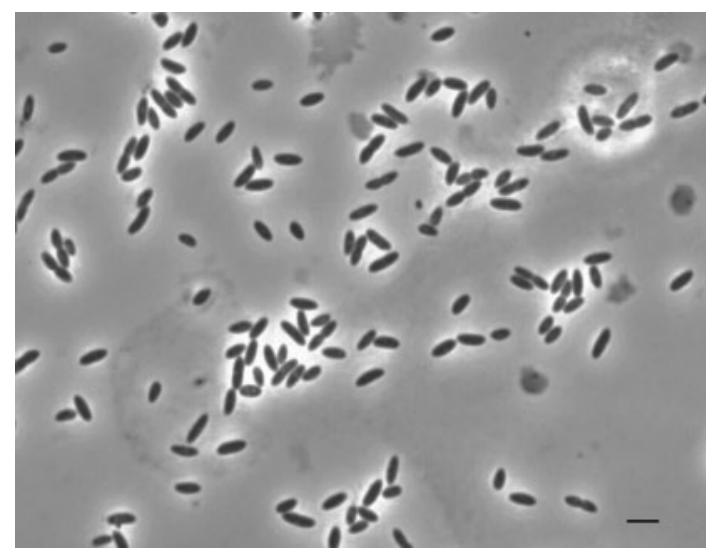

Fig. 1. Phase-contrast micrograph of cells of strain $\mathrm{HB} 1^{\top}$ growing on butyrate in the presence of sulfate. Bar, $2.5 \mu \mathrm{m}$. 
$1^{-1}$. Under optimal conditions, the doubling time of the isolate in media with butyrate and sulfate was about $130 \mathrm{~h}$ $\left(\mu_{\max }=0.0037 \mathrm{~h}^{-1}\right)$ and the final cell density $\left(\mathrm{OD}_{600}\right)$ was about 0.38 .

Strain $\mathrm{HB} 1^{\mathrm{T}}$ was mesophilic. Growth occurred between 15 and $37^{\circ} \mathrm{C}$, with an optimum growth temperature of 28 $30{ }^{\circ} \mathrm{C}$. Growth was possible at $\mathrm{pH} 6.5-8.0$, with an optimum at $\mathrm{pH}$ 7.0. Growth was observed in $0-15 \mathrm{~g}$ $\mathrm{NaCl} l^{-1}$, with an optimum around $5 \mathrm{~g} \mathrm{NaCl} \mathrm{l}^{-1}$.

The $\mathrm{G}+\mathrm{C}$ content of the DNA was determined by using standard HPLC analysis (Mesbah et al., 1989) at the Deutsche Sammlung von Mikroorganismen und Zellkulturen GmbH (Braunschweig, Germany). Genomic DNA was isolated according to the procedure of Cashion et al. (1977).

Organic compounds were measured by HPLC as described previously by Stams et al., (1993). Gases and alcohols were measured by gas chromatography (Balk et al., 2003; Henstra \& Stams, 2004) and thiosulfate, nitrate and sulfate were analysed by an HPLC system equipped with an Ionpac AS9-SC column and an ED 40 electrochemical detector (Dionex) (Scholten \& Stams, 1995). Sulfide was analysed by the method of Trüper \& Schlegel (1964).

Strain $\mathrm{HB1}^{\mathrm{T}}$ used the following substrates as electron donors and carbon sources (tested at $20 \mathrm{mM}$, unless indicated): $\mathrm{H}_{2}$ /acetate $(1.7 \mathrm{bar} / 2 \mathrm{mM})$, formate, ethanol $(5 \mathrm{mM})$, propionate, 1-propanol $(5 \mathrm{mM})$, 1-butanol (5 mM), 2,3-butandiol (5 mM), fumarate, succinate, butyrate $(10 \mathrm{mM})$, crotonate, catechol $(0.5 \mathrm{mM})$, phenol $(1 \mathrm{mM})$, benzoate $(3 \mathrm{mM})$, 4-hydroxybenzoate $(3 \mathrm{mM})$, palmitate $(5 \mathrm{mM})$ and stearate $(2 \mathrm{mM})$. Growth on ethanol, propionate, crotonate and benzoate was much faster than on butyrate. Growth on pyruvate and crotonate was possible without an electron acceptor. The strain was not able to grow on $\mathrm{H}_{2} / \mathrm{CO}_{2}$, methanol, acetone, lactate, malate, glucose or fructose. Slight growth was observed on acetate in the presence of sulfate. A maximum $2 \mathrm{mM}$ acetate was utilized by strain $\mathrm{HB}^{\mathrm{T}}$ during 3 weeks of incubation and acetate was not fully oxidized, even after longer incubations. Aromatic compounds including catechol, phenol, benzoate and 4-hydroxybenzoate were oxidized completely by strain $\mathrm{HB}^{\mathrm{T}}$.
Sulfate $(20 \mathrm{mM})$ and thiosulfate $(20 \mathrm{mM})$ were used as electron acceptors, but nitrate $(10 \mathrm{mM})$, sulfite $(5 \mathrm{mM})$ and elemental sulfur $\left(0.5 \mathrm{~g} \mathrm{l}^{-1}\right)$ were not. Thiosulfate and sulfite were not disproportionated.

Butyrate was oxidized completely by strain $\mathrm{HB}^{\mathrm{T}}$. After 28 days of incubation in the presence of sulfate, no acetate was detected, and the molar ratio of the butyrate oxidized $(7.2 \mathrm{mmol})$ to sulfide formed $(16.0 \mathrm{mmol})$ of $1: 2.23$ was close to the expected theoretical values for the complete oxidation of butyrate according to the following reaction:

$2 \mathrm{CH}_{3} \mathrm{CH}_{2} \mathrm{CH}_{2} \mathrm{COO}^{-}+5 \mathrm{SO}_{4}^{2-} \rightarrow 8 \mathrm{HCO}_{3}^{-}+5 \mathrm{HS}^{-}+\mathrm{H}^{+}$

DNA was extracted as described by Zoetendal et al. (1998). PCR was performed with the bacterial primers $7 \mathrm{f}$ and $1510 \mathrm{r}$ (Lane, 1991) by using the Taq DNA polymerase kit (Life Technologies) to amplify the bacterial $16 \mathrm{~S}$ rRNA gene. PCR products were purified with the QIAquick PCR purification kit (Qiagen) according to the manufacturer's instructions. Sequencing of the complete 16S rRNA gene was performed at Westburg Genomics (http://genomics. westburg.nl). A total of 1535 nucleotides of the $16 \mathrm{~S}$ rRNA gene were sequenced. The sequences were checked for reading errors with the alignment programs of the ARB package (Ludwig et al. 2004), and a rooted neighbourjoining tree was constructed using Escherichia coli ATCC $11775^{\mathrm{T}}$ as an outgroup (Fig. 2). Online similarity analysis of the 16S rRNA gene sequences was performed with the BLAST program at the GenBank and EMBL databases. The closest phylogenetic relatives of strain $\mathrm{HB}^{\mathrm{T}}$ were Desulfococcus multivorans DSM 2059 ${ }^{\mathrm{T}}$, Desulfococcus biacutus DSM $5651^{\mathrm{T}}$ (sequence similarity of $91 \%$ to both) and Desulfobacterium indolicum DSM $3383^{\mathrm{T}}$ (90\%) (Fig. 2).

For lipid analyses, bacterial cultures of strain $\mathrm{HB}^{\mathrm{T}}$ grown on crotonate were harvested by centrifugation $(14500 \mathrm{~g}$, $20 \mathrm{~min}, 4{ }^{\circ} \mathrm{C}$ ) and pellets were washed with distilled water. Lipids from lyophilized cells were extracted ultrasonically using a mixture of dichloromethane (DCM) and methanol $(2: 1, \mathrm{v} / \mathrm{v})$ and this procedure was repeated four times. The residue was saponified with $1 \mathrm{M} \mathrm{KOH}$ in $96 \%$ methanol by refluxing for $1 \mathrm{~h}$ and subsequently neutralized and extracted with DCM. After addition of internal standards, the free and bound lipid extracts were methylated and

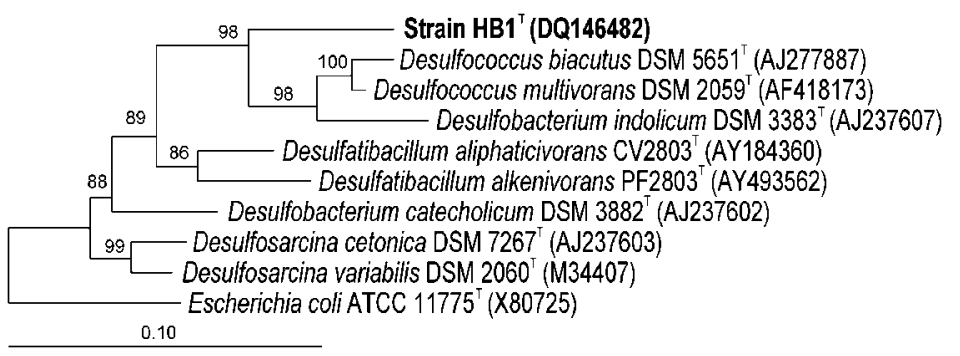

Fig. 2. Dendrogram showing the position of strain $\mathrm{HB}^{\top}$ among related bacteria. Phylogenetic analysis was based on $16 \mathrm{~S}$ rRNA gene sequences available from GenBank (accession numbers in parentheses). The neighbour-joining tree was reconstructed from distance matrices; bootstrap values above $50 \%$ are expressed at branching points. Escherichia coli ATCC $11775^{\top}$ served as the outgroup. Bar, evolutionary distance of 0.10 . 
silylated and subsequently analysed by GC and GC-mass spectrometry (GC-MS). The most abundant fatty acids of strain $\mathrm{HB}^{\mathrm{T}}$ were $\mathrm{C}_{16: 0}$, iso- $\mathrm{C}_{15: 0}$, anteiso- $\mathrm{C}_{15: 0}$ and $\mathrm{C}_{14: 0}$ (Table 1). After saponification of the residue, $\beta$-hydroxy fatty acids were also present in the range of $\mathrm{C}_{14: 0}$ to $\mathrm{C}_{18: 0}$, of which $\mathrm{C}_{16: 0}$ was the most abundant. The $\mathrm{C}_{35}$ lipid bacteriohopanetetrol was also present in small amounts (approx. $1 \%$ of total lipids).

The presence of the fatty acids iso- $\mathrm{C}_{15: 0}$, anteiso- $\mathrm{C}_{15: 0}$ and $\mathrm{C}_{16: 0}$ as major components is also characteristic for Desulfococcus multivorans grown on benzoate (Kohring et al., 1994), but the lipid profile of Desulfococcus multivorans differs from that of strain $\mathrm{HB}^{\mathrm{T}}$ by the predominance of anteiso- $\mathrm{C}_{17: 0}$. The predominant fatty acids of strain $\mathrm{HB}^{\mathrm{T}}$ were iso- $\mathrm{C}_{15: 0}$ and anteiso- $\mathrm{C}_{15: 0}$. This is not the case for Desulfobacterium species grown on benzoate (Kohring et al., 1994). Bacteriohopanetetrol derivatives have recently been identified in sulfate reducers (Blumenberg et al. 2006); the presence of this lipid in strain $\mathrm{HB}^{\mathrm{T}}$ fits this pattern.

Based on morphological and physiological differences from members of the class Deltaproteobacteria, it is proposed that strain $\mathrm{HB}^{\mathrm{T}}$ represents a novel species in a new genus. Characteristics that differentiate strain $\mathrm{HB}^{\mathrm{T}}$ from phylogenetically related species are given in Table 2; other detailed characteristics determined are given in the species description below.

The 16S rRNA gene sequence, physiological and morphological characteristics of strain $\mathrm{HB}^{\mathrm{T}}$ were quite different from those of its phylogenetic neighbours. In addition, the

Table 1. Lipid composition of strain $\mathrm{HB} 1^{\top}$

Values are percentages of total quantified lipids. -, Not detected.

\begin{tabular}{|c|c|c|c|}
\hline Fatty acid & $\begin{array}{l}\text { Free lipid } \\
\text { fraction }\end{array}$ & $\begin{array}{l}\text { Free and bound } \\
\text { lipid fraction }\end{array}$ & $\begin{array}{l}\text { Residual bound } \\
\text { lipid fraction }\end{array}$ \\
\hline iso- $\mathrm{C}_{14: 0}$ & 2 & 1 & - \\
\hline $\mathrm{C}_{14: 0}$ & 11 & 7 & 4 \\
\hline iso- $\mathrm{C}_{15: 0}$ & 17 & 14 & 17 \\
\hline anteiso- $\mathrm{C}_{15: 0}$ & 21 & 17 & 6 \\
\hline $\mathrm{C}_{16: 1}$ & 7 & 5 & - \\
\hline$C_{16: 0}$ & 31 & 34 & 39 \\
\hline iso- $\mathrm{C}_{17}$ & 1 & 1 & 3 \\
\hline$C_{17: 1}$ & 2 & 2 & - \\
\hline $\mathrm{C}_{18: 1}$ & 1 & 1 & - \\
\hline $\mathrm{C}_{18: 0}$ & 6 & 16 & 12 \\
\hline$\beta-\mathrm{OH}-\mathrm{C}_{14: 0}$ & - & - & 2 \\
\hline $\begin{array}{l}\text { iso } \beta-\mathrm{OH}- \\
\mathrm{C}_{15: 0}\end{array}$ & - & - & 1 \\
\hline$\beta-\mathrm{OH}-\mathrm{C}_{16: 0}$ & - & - & 11 \\
\hline $\begin{array}{l}\text { iso } \beta-\mathrm{OH}- \\
\mathrm{C}_{17: 0}\end{array}$ & - & - & 1.5 \\
\hline$\beta-\mathrm{OH}-\mathrm{C}_{18: 0}$ & - & - & 0.5 \\
\hline
\end{tabular}

closest similarity (91\%) of the $16 \mathrm{~S}$ rRNA gene sequence of strain $\mathrm{HB}^{\mathrm{T}}$ with a recognized bacterium (the type strain of Desulfococcus multivorans) was much lower than the threshold level that is generally used to define a new genus (Ludwig et al., 2004). Therefore, we propose that isolate $\mathrm{HB}^{\mathrm{T}}{ }^{\mathrm{s}}$ should be classified as representing a novel species in a new genus, Desulfatirhabdium butyrativorans gen. nov., sp. nov., within the family Desulfobacteraceae, class Deltaproteobacteria.

\section{Description of Desulfatirhabdium gen. nov.}

Desulfatirhabdium (De.sul.fa'ti.rhab'di.um. L. pref. defrom; N.L. masc. n. sulfas -atis sulfate; Gr. neut. n. rhabdium a little rod; N.L. neut. n. Desulfatirhabdium a sulfate-reducing small rod).

Cells are anaerobic, Gram-negative, non-spore-forming and oval to rod-shaped. Thiosulfate and sulfate are reduced to sulfide. Volatile fatty acids are oxidized completely. Predominant cellular fatty acids are iso- $\mathrm{C}_{15: 0}$, anteiso$\mathrm{C}_{15: 0}, \mathrm{C}_{16: 0}$ and $\mathrm{C}_{14: 0}$. Phylogenetically, the genus belongs to the family Desulfobacteraceae in the class Deltaproteobacteria. The type species is Desulfatirhabdium butyrativorans.

\section{Description of Desulfatirhabdium butyrativorans sp. nov.}

Desulfatirhabdium butyrativorans (bu.ty.ra.ti.vo' rans. N.L. n. butyras -atis butyrate; L. part. adj. vorans devouring; N.L. part. adj. butyrativorans butyrate-devouring).

Displays the following properties in addition to those described for the genus. Cells are $1-1.3 \times 2.6-3.5 \mu \mathrm{m}$. Colonies are brownish, lens-shaped in the agar after about 1 month of incubation. Growth occurs at $15-37^{\circ} \mathrm{C}$ (optimum $28-30{ }^{\circ} \mathrm{C}$ ) and $\mathrm{pH}$ 6.5-8.0 (optimum $\mathrm{pH}$ 7.0). Growth occurs at $\mathrm{NaCl}$ concentrations of $0-15 \mathrm{~g} \mathrm{NaCl} \mathrm{l}^{-1}$, with an optimum at $5 \mathrm{~g} \mathrm{NaCl} \mathrm{l}^{-1}$. Sulfate and thiosulfate are used as electron acceptors. In the presence of an electron acceptor, growth occurs on $\mathrm{H}_{2} /$ acetate (1.7 bar/ $2 \mathrm{mM})$, formate $(20 \mathrm{mM})$, ethanol $(5 \mathrm{mM})$, pyruvate $(20 \mathrm{mM})$, propionate $(20 \mathrm{mM})$, propanol $(5 \mathrm{mM})$, 1butanol $(5 \mathrm{mM})$, 2,3-butandiol $(5 \mathrm{mM})$, fumarate $(20 \mathrm{mM})$, succinate $(20 \mathrm{mM})$, 1-butyrate $(10 \mathrm{mM})$, crotonate $(20 \mathrm{mM})$, catechol $(0.5 \mathrm{mM})$, phenol $(1 \mathrm{mM})$, benzoate $(3 \mathrm{mM})$, 4-hydroxybenzoate $(3 \mathrm{mM})$, palmitate $(5 \mathrm{mM})$ and stearate $(2 \mathrm{mM})$. Only slight growth is observed on acetate. Fermentative growth occurs on pyruvate and crotonate. Not able to grow on $\mathrm{H}_{2} / \mathrm{CO}_{2}$, methanol, acetone, lactate, malate, glucose or fructose. $\beta$ Hydroxy fatty acids are present in the range of $\mathrm{C}_{14: 0}$ to $\mathrm{C}_{18: 0}$, of which $\mathrm{C}_{16: 0}$ was the most abundant. The DNA $\mathrm{G}+\mathrm{C}$ content of the type strain is $55.1 \mathrm{~mol} \%$.

The type strain, $\mathrm{HB1}^{\mathrm{T}}\left(=\mathrm{DSM} 18734^{\mathrm{T}}=\mathrm{JCM} 14470^{\mathrm{T}}\right)$, was isolated from a UASB reactor treating paper-mill wastewater operated at $37{ }^{\circ} \mathrm{C}$ with butyrate as the energy source. 
Table 2. Characteristics of strain $\mathrm{HB}^{\top}$ and related representatives of the genera Desulfococcus and Desulfobacterium

Data for reference species were obtained from Widdel (1980), Bak \& Widdel (1986) and Platen et al. (1990). NR, Not reported; (+) weak growth. All taxa use ethanol and propionate as electron donors and sulfate as an electron acceptor.

\begin{tabular}{|c|c|c|c|c|}
\hline Characteristic & Strain $H B 1^{T}$ & $\begin{array}{l}\text { Desulfococcus } \\
\text { multivorans }\end{array}$ & $\begin{array}{c}\text { Desulfococcus } \\
\text { biacutus }\end{array}$ & $\begin{array}{c}\text { Desulfobacterium } \\
\text { indolicum }\end{array}$ \\
\hline Morphology & Oval to rod & Spherical & Lemon & Oval to rod \\
\hline Origin & Anaerobic reactor & Sewage digester & Sewage digester & Marine sediment \\
\hline DNA G $+\mathrm{C}$ content $(\mathrm{mol} \%)$ & 55.1 & 57 & 56.5 & 47.4 \\
\hline Optimum temperature $\left({ }^{\circ} \mathrm{C}\right)$ & $28-30$ & 35 & $20-30$ & 28 \\
\hline Optimum pH & 7.0 & NR & $6.8-7.8$ & 7.0 \\
\hline Optimum salinity ( $\mathrm{g} \mathrm{NaCl}^{-1}$ ) & 5 & 5 & - & 20 \\
\hline \multicolumn{5}{|l|}{ Electron donors } \\
\hline $\mathrm{H}_{2} / \mathrm{CO}_{2}$ & - & - & NR & - \\
\hline Formate & + & + & $\mathrm{NR}$ & + \\
\hline Acetate & $(+)$ & $(+)$ & $(+)$ & + \\
\hline Pyruvate & + & NR & + & + \\
\hline Lactate & - & + & - & - \\
\hline Acetone & - & + & + & $\mathrm{NR}$ \\
\hline Propanol & + & NR & + & + \\
\hline Fumarate & + & - & - & + \\
\hline Succinate & + & - & - & + \\
\hline Malate & - & - & - & + \\
\hline Butanol & + & NR & + & + \\
\hline Butyrate & + & + & + & - \\
\hline Catechol & + & NR & $\mathrm{NR}$ & - \\
\hline Benzoate & + & + & - & - \\
\hline Palmitate & + & NR & NR & NR \\
\hline Stearate & + & NR & NR & NR \\
\hline \multicolumn{5}{|l|}{ Electron acceptors } \\
\hline Thiosulfate & + & + & NR & + \\
\hline Sulfite & - & + & + & $\mathrm{NR}$ \\
\hline Nitrate & - & - & - & $\mathrm{NR}$ \\
\hline
\end{tabular}

\section{Acknowledgements}

We are grateful to Professor Dr Hans G. Trüper and Dr Jean P. Euzéby for their suggestions and help with nomenclature. We thank Wim van Doesburg for his technical assistance on this study. This work was supported by the Darwin Center for Biogeology of the Netherlands Organization for Scientific Research (NWO).

\section{References}

Bak, F. \& Widdel, F. (1986). Anaerobic degradation of indolic compounds by sulfate-reducing enrichment cultures, and description of Desulfobacterium indolicum gen. nov., sp. nov. Arch Microbiol 146, 170-176.

Balk, M., Weijma, J., Friedrich, M. W. \& Stams, A. J. M. (2003). Methanol utilization by a novel thermophilic homoacetogenic bacterium, Moorella mulderi sp. nov., isolated from a bioreactor. Arch Microbiol 179, 315-320.

Blumenberg, M., Krüger, M., Nauhaus, K., Talbot, H. M., Oppermann, B. I., Seifert, R., Pape, T. \& Michaelis, W. (2006). Biosynthesis of hopanoids by sulfate-reducing bacteria (genus Desulfovibrio). Environ Microbiol 8, 1220-1227.

Brandt, K. K., Patel, B. K. C. \& Ingvorsen, K. (1999). Desulfocella halophila gen. nov., sp. nov., a halophilic, fatty-acid-oxidizing, sulfate-reducing bacterium isolated from sediments of the Great Salt Lake. Int J Syst Bacteriol 49, 193-200.

Brysch, K., Schneider, C., Fuchs, G. \& Widdel, F. (1987). Lithoautotrophic growth of sulfate-reducing bacteria, and description of Desulfobacterium autotrophicum. Arch Microbiol 148, 264-274.

Campbell, L. L. \& Postgate, J. R. (1965). Classification of the sporeforming sulfate-reducing bacteria. Bacteriol Rev 29, 359-363.

Canfield, D. E., Jorgensen, B. B., Fossing, H., Glud, R., Gundersen, J., Ramsing, N. B., Thamdrup, B., Hansen, J. W., Nielsen, L. P. \& Hall, P. O. (1993). Pathways of organic carbon oxidation in three continental margin sediments. Mar Geol 113, 27-40.

Cashion, P., Holder-Franklin, M. A., McCully, J. \& Franklin, M. (1977). A rapid method for the base ratio determination of bacterial DNA. Anal Biochem 81, 461-466.

Colleran, E., Finnegan, S. \& Lens, P. (1995). Anaerobic treatment of sulfate-containing waste streams. Antonie van Leeuwenhoek 67, 29-46.

Cravo-Laureau, C., Matheron, R., Joulian, C., Cayol, J. L. \& HirschlerRéa, A. (2004). Desulfatibacillum alkenivorans sp. nov., a novel nalkene-degrading, sulfate-reducing bacterium, and emended description of the genus Desulfatibacillum. Int J Syst Evol Microbiol 54, 1639-1642.

Glud, R. N., Risgaard-Petersen, N., Thamdrup, B., Fossing, H. \& Rysgaard, S. (2000). Benthic carbon mineralization in a high-Arctic sound (Young Sound, NE Greenland). Mar Ecol Prog Ser 206, 59-71. 
Gogotova, G. I. \& Vainstein, M. B. (1989). Description of sulfatereducing bacterium Desulfobacterium macestii sp. nov. capable of autotrophic growth. Mikrobiologiia 58, 76-80 (in Russian).

Henry, E. A., Devereux, R., Maki, J. S., Gilmour, C. C., Woese, C. R., Mandelco, L., Schauder, R., Remsen, C. C. \& Mitchell, R. (1994). Characterization of a new thermophilic sulfate-reducing bacterium Thermodesulfovibrio yellowstonii, gen. nov. and sp. nov.: its phylogenetic relationship to Thermodesulfobacterium commune and their origins deep within the bacterial domain. Arch Microbiol 161, 62-69.

Henstra, A. M. \& Stams, A. J. M. (2004). Novel physiological features of Carboxydothermus hydrogenoformans and Thermoterrabacterium ferrireducens. Appl Environ Microbiol 70, 7236-7240.

Jørgensen, B. B. (1982). Mineralization of organic matter in the sea bed - the role of sulfate reduction. Nature 296, 643-645.

Kjeldsen, K. U., Loy, A., Jakobsen, T. F., Thomsen, T. R., Wagner, M. \& Ingvorsen, K. (2007). Diversity of sulfate-reducing bacteria from an extreme hypersaline sediment, Great Salt Lake (Utah). FEMS Microbiol Ecol 60, 287-298.

Kohring, L. L., Ringelberg, D. B., Devereux, R., Stahl, D. A., Mittelman, M. W. \& White, D. C. (1994). Comparison of phylogenetic relationships based on phospholipid fatty acid profiles and ribosomal RNA sequence similarities among dissimilatory sulfate-reducing bacteria. FEMS Microbiol Lett 119, 303-308.

Kostka, J. E., Thamdrup, B., Glud, R. N. \& Canfield, D. E. (1999). Rates and pathways of carbon oxidation in permanently cold Arctic sediments. Mar Ecol Prog Ser 180, 7-21.

Kuever, J., Rainey, F. A. \& Widdel, F. (2005). Family I. Desulfobacteraceae fam. nov. In Bergey's Manual of Systematic Bacteriology, 2nd edn, vol. 2, part C, pp. 959-960. Edited by D. J. Brenner, N. R. Krieg, J. T. Staley \& G. M. Garrity. New York: Springer.

Lane, D. J. (1991). 16S/23S rRNA sequencing. In Nucleic Acid Techniques in Bacterial Systematics, pp. 115-175. Edited by E. Stackebrandt \& M. Goodfellow. Chichester: Wiley.

Ludwig, W., Strunk, O., Westram, R., Richter, L., Meier, H., Yadhukumar, Buchner, A., Lai, T., Steppi, S., Jobb, G. \& other authors (2004). ARB: a software environment for sequence data. Nucleic Acids Res 32, 1363-1371.

Mesbah, M., Premachandran, U. \& Whitman, W. B. (1989). Precise measurement of the $\mathrm{G}+\mathrm{C}$ content of deoxyribonucleic acid by highperformance liquid chromatography. Int J Syst Bacteriol 39, 159-167.

Mori, K., Kim, H., Kakegawa, T. \& Hanada, S. (2003). A novel lineage of sulfate-reducing microorganisms: Thermodesulfobiaceae fam. nov., Thermodesulfobium narugense, gen. nov., sp. nov., a new thermophilic isolate from a hot spring. Extremophiles 7, 283-290.

Moussard, H., L'Haridon, S., Tindall, B. J., Banta, A., Schumann, P., Stackebrandt, E., Reysenbach, A.-L. \& Jeanthon, C. (2004). Thermodesulfatator indicus gen. nov., sp. nov., a novel thermophilic chemolithoautotrophic sulfate-reducing bacterium isolated from the Central Indian Ridge. Int J Syst Evol Microbiol 54, 227-233.

Murray, R. G. E., Doetsch, R. N. \& Robinow, C. F. (1994). Determinative and cytological light microscopy. In Methods of General and Molecular Biology, pp. 21-41. Edited by P. Gerhardt, R. G. E. Murray, W. A. Wood \& N. R. Krieg. Washington, DC: American Society for Microbiology.

Oude Elferink, S. J. W. H., Lens, P. N. L., Dijkema, C. \& Stams, A. J. M. (1994). Sulfate reduction in methanogenic bioreactors. FEMS Microbiol Lett 142, 237-241.

Oude Elferink, S. J. W. H., Boschker, H. T. S. \& Stams, A. J. M. (1998). Identification of sulfate reducers and Syntrophobacter sp. in anaerobic granular sludge by fatty acid biomarkers and $16 \mathrm{~S}$ rRNA probing. Geomicrobiol J 15, 3-17.
Platen, H., Temmes, A. \& Schink, B. (1990). Anaerobic degradation of acetone by Desulfococcus biacutus sp. nov. Arch Microbiol 154, 355-361.

Rabus, R., Hansen, T. A. \& Widdel, F. (2006). Dissimilatory sulfateand sulfur-reducing prokaryotes. In The Prokaryotes. A Handbook on the Biology of Bacteria, 3rd edn, vol. 2, pp 659-768. Edited by M. Dworkin, S. Falkow, E. Rosenberg, K. H. Schleifer \& E. Stackebrandt. New York: Springer.

Rees, G. N. \& Patel, B. K. (2001). Desulforegula conservatrix gen. nov., sp. nov., a long-chain fatty acid-oxidizing, sulfate-reducing bacterium isolated from sediments of a freshwater lake. Int J Syst Evol Microbiol 51, 1911-1916.

Roest, K., Heilig, H. G., Smidt, H., de Vos, W. M., Stams, A. J. \& Akkermans, A. D. (2005). Community analysis of a full-scale anaerobic bioreactor treating paper mill wastewater. Syst Appl Microbiol 28, 175-185.

Rysgaard, S., Thamdrup, B., Risgaard-Petersen, N., Fossing, H., Berg, P., Christensen, P. B. \& Dalsgaard, T. (1998). Seasonal carbon and nutrient mineralization in a high-Arctic coastal marine sediment, Young Sound, Northeast Greenland. Mar Ecol Prog Ser 175, 261-276.

Schnell, S., Bak, F. \& Pfennig, N. (1989). Anaerobic degradation of aniline and dihydroxybenzenes by newly isolated sulfate-reducing bacteria and description of Desulfobacterium anilini. Arch Microbiol 152, 556-563.

Scholten, J. C. \& Stams, A. J. M. (1995). The effect of sulfate and nitrate on methane formation in a freshwater sediment. Antonie van Leeuwenhoek 68, 309-315.

Stams, A. J. M., Veenhuis, M., Weenk, G. H. \& Hansen, T. A. (1983). Occurrence of polyglucose as a storage polymer in Desulfovibrio species and Desulfobulbus propionicus. Arch Microbiol 136, 54-59.

Stams, A. J. M., van Dijk, J. B., Dijkema, C. \& Plugge, C. M. (1993). Growth of syntrophic propionate-oxidizing bacteria with fumarate in the absence of methanogenic bacteria. Appl Environ Microbiol 59, 1114-1119.

Stieb, M. \& Schink, B. (1989). Anaerobic degradation of isobutyrate by methanogenic enrichment cultures and by a Desulfococcus multivorans strain. Arch Microbiol 151, 126-132.

Szewzyk, R. \& Pfennig, N. (1987). Complete oxidation of catechol by strictly anaerobic sulfate-reducing Desulfobacterium catecholicum sp. nov. Arch Microbiol 147, 163-168.

Thamdrup, B. \& Canfield, D. E. (1996). Pathways of carbon oxidation in continental margin sediments of central Chile. Limnol Oceanogr 41, $1629-1650$.

Trüper, H. G. \& Schlegel, H. G. (1964). Sulphur metabolism in Thiorhodaceae. I. Quantitative measurements on growing cells of Chromatium okenii. Antonie van Leeuwenhoek 30, 225-238.

Widdel, F. (1980). Anaerober Abbau von Fettsäuren und Benzoesäure durch neu Isolierte Arten Sulfat-reduzierender Bakterien. PhD thesis, Göttingen University, Germany (in German).

Widdel, F. \& Bak, F. (1992). Gram-negative mesophilic sulfatereducing bacteria. In The Prokaryotes, 2nd edn., vol. 4, pp. 3352-3378. Edited by A. Balows, H. G. Trüper, M. Dworkin, W. Harder \& K. H. Schleifer. New York: Springer.

Zeikus, J. G., Dawson, M. A., Thompson, T. E., Ingvorsen, K. \& Hatchikian, E. C. (1983). Microbial ecology of volcanic sulfidogenesis: isolation and characterization of Thermodesulfobacterium commune gen. nov. and sp. nov. J Gen Microbiol 129, 1159-1169.

Zoetendal, E. G., Akkermans, A. D. L. \& de Vos, W. M. (1998). Temperature gradient gel electrophoresis from human fecal samples reveals stable and host-specific communities of bacteria. Appl Environ Microbiol 64, 3854-3859. 